\title{
V3 Region Polymorphisms in HIV-1 from Brazil: Prevalence of Subtype B Strains Divergent from North American/European Prototype and Detection of Subtype F
}

\author{
MARIZA G. MORGADO,${ }^{1}$ ESTER C. SABINO,${ }^{2,3}$ EUGENE G. SHPAER,${ }^{4}$ VERA BONGERTZ, ${ }^{1}$ \\ LUIS BRIGIDO, ${ }^{2}$ MARK D. C. GUIMARAES,${ }^{5,6}$ EUCLIDES A. CASTILHO, ${ }^{5}$ \\ BERNARDO GALVÃO-CASTRO,${ }^{7}$ JAMES I. MULLINS,${ }^{4}$ R. MICHAEL HENDRY,${ }^{8}$ \\ and ALLEN MAYER ${ }^{3}$
}

\begin{abstract}
Viral DNA sequences were determined over the $\mathrm{V} 3$ region of $e n v$ from 28 infected individuals living in the high HIV-1 prevalence Brazilian cities of Rio de Janeiro and São Paulo. Twenty-six belonged to envelope sequence subtype B, prevalent in North America and Europe, and one was classified as subtype F, found recently in Brazil and in Romania (one appeared to be a B/F recombinant). Octameric sequences at the tip of the subtype B V3 loops were variable and distinct from those prevalent in North America and Europe. The GPGR motif, prevalent in North American/European strains, was found in only $8(28.5 \%)$ sequences, whereas GWGR was found in $12(43 \%)$ and novel sequences in $8(28.5 \%)$. Brazilian subtype $B$ sequences also diverged from the consensus North American/European strains over the remainder of the V3 loop. These results suggest that Brazilian HIV-1 B strains may have important antigenic differences from prototype subtype B strains currently being evaluated for use in HIV vaccines. These results should be taken into account for future vaccine programs in Brazil.
\end{abstract}

\section{INTRODUCTION}

$\mathbf{H}$ UMAN IMMUNODEFICIENCY VIRUS type 1 (HIV-1) isolates have been found to differ in terms of replication rate, cell infectivity, cytopathicity, and cellular tropism. Some of these biological properties seem to be correlated with in vivo pathogenesis of HIV-1. ${ }^{1-3}$ HIV-1 in vivo has also been shown to consist of a population of related genomes that can change with time. ${ }^{4}$ Serologically defined subtypes of HIV-1 have been reported, ${ }^{2}$ and seven sequence-defined subtypes have been defined that differ by up to $35 \%$ in the surface (SU) coding portion of the $e n v$ gene. ${ }^{5}$ In contrast, the diversity within an individual usually ranges up to no more than 7\%.5.6 The importance of this genetic variation in terms of pathogenesis and vaccine development has been discussed by Wolfs $e t a l{ }^{7}$

The highly variable V3 region of the envelope glycoprotein gp120 is functionally important in that it (1) is a determinant for $T$ cell and macrophage cellular tropism, ${ }^{8-10}(2)$ is involved in determining syncytium induction phenotype and replication rate, ${ }^{11,12}$ (3) contains the epitope recognized by antibodies that neutralize HIV infection in vitro, the so-called principal neutralizing determinant (PND), ${ }^{13-16}$ and (4) stimulates a potent immune response by cytotoxic and helper $\mathrm{T}$ lymphocytes. ${ }^{17-19}$ Because of its biological functions and the role it may play in the

\footnotetext{
'Department of Immunology, Instituto Oswaldo Cruz, FIOCRUZ, Rio de Janeiro 21045, Brazil.

${ }^{2}$ Instituto Adolfo Lutz, São Paulo 01246, Brazil.

${ }^{3}$ Irwin Memorial Blood Centers, San Francisco, California 94118.

${ }^{4}$ Department of Microbiology and Immunology, School of Medicine, Stanford University, Stanford, California 94305-5402.

${ }^{5}$ Centro de Info para a Saude, Instituto Oswaldo Cruz, FIOCRUZ, Rio de Janeiro 21045, Brazil.

${ }^{6}$ Department of Preventive Medicine, Minas Gerais University, Minas Gerais 30.130-000, Brazil.

${ }^{7}$ Laboratorio Avancado de Saude Publica, Centro de Pesquisa Goncalo Moniz, FIOCRUZ, Bahia 45945, Brazil.

${ }^{8}$ Viral and Rickettsial Disease Laboratory, California Department of Health Services, Berkeley, California 94704.
} 
induction of a protective immune response, this region of the envelope protein has been considered to be important for inclusion in vaccines.

Although Brazil ranks third to fourth in the world in the absolute number of reported AIDS cases, information is scarce with regard to the molecular diversity of Brazilian HIV-1 strains, ${ }^{20,21}$ and the relationship of Brazilian sequences to those found in other parts of the world. Serological studies using peptides corresponding to the V3 region of different HIV-1 strains showed a lower reactivity of sera from Brazil against the prevalent North American/European MN strain than was seen with sera from North America, Europe, and even Africa. ${ }^{22,23}$

We have evaluated the degree of polymorphism among Brazilian HIV-1 genomes by sequencing the env V3 region, amplified by polymerase chain reaction (PCR) directly from peripheral blood mononuclear cells (PBMCs) of HIV-1-infected people living in Rio de Janeiro and São Paulo, cities of high incidence of HIV-1 infection. We have observed significant differences between the V3 sequences in Brazilian HIV-1 and those in the North American/European envelope protein currently in development for use as recombinant vaccines. The differences reported here may represent potential constraints on the effectiveness of these recombinant vaccines in Brazil.

\section{MATERIALS AND METHODS}

\section{Patient population}

HIV-1-infected individuals belonging to the cohort of patients enrolled in a multicentric study of heterosexual transmission of HIV in Rio de Janeiro $(n=28)$, and four patients from São Paulo attending the AIDS clinic at the Adolpho Lutz Institute, were included in this study (Table 1). Samples were obtained in 1990 , 1991, and 1992. All patients were serologically positive as confirmed by enzyme-linked immunosorbent assay (ELISA),

Table 1. Summary of Epidemiological and Laboratory Data for Brazilian Subjects

\begin{tabular}{|c|c|c|c|c|c|}
\hline Subject ${ }^{a}$ & Year & Risk group $^{b}$ & Sex & $\begin{array}{c}C D C \text { clinical } \\
\text { class }\end{array}$ & $\begin{array}{l}C D 4^{+} \text {cells } \\
\left(\text { per } \mathrm{mm}^{3}\right)\end{array}$ \\
\hline RJ 12 & 1990 & Heterosexual & $\mathbf{F}$ & II & 444 \\
\hline RJ 14 & 1990 & Bisexual & $\mathbf{M}$ & II & $N^{c}$ \\
\hline RJ 17 & 1990 & Blood product & $\mathbf{M}$ & II & 563 \\
\hline RJ 19 & 1990 & Blood product & $\mathbf{M}$ & II & 697 \\
\hline RJ 27 & 1990 & Bisexual & $\mathbf{M}$ & IV & 090 \\
\hline $\mathrm{RJ} 33^{\mathrm{d}}$ & 1990 & Heterosexual & $\mathrm{F}$ & III & 332 \\
\hline RJ 49 & 1990 & Heterosexual & $\mathbf{M}$ & III & 1279 \\
\hline RJ 54 & 1990 & Heterosexual & $\mathbf{F}$ & II & 684 \\
\hline RJ 59 & 1990 & Heterosexual & $\mathbf{F}$ & II & 433 \\
\hline RJ 62 & 1990 & Heterosexual & $\mathbf{F}$ & II & 704 \\
\hline RJ 64 & 1990 & Heterosexual & $\mathrm{F}$ & NA & 204 \\
\hline RJ 70 & 1990 & Bisexual/IVDU & $\mathbf{M}$ & IV & 635 \\
\hline RJ $370^{d}$ & 1991 & Bisexual & $\mathbf{M}$ & II & 503 \\
\hline RJ 379 & 1991 & Heterosexual & $\mathbf{F}$ & II & 657 \\
\hline RJ 477 & 1992 & Heterosexual & $\mathbf{M}$ & II & 981 \\
\hline RJ 478 & 1992 & Heterosexual & $\mathbf{F}$ & II & 401 \\
\hline RJ 483 & 1992 & Heterosexual & $\mathbf{M}$ & NA & 496 \\
\hline RJ 484 & 1992 & Heterosexual & $\mathbf{F}$ & NA & 247 \\
\hline $\mathrm{RJ} 485^{\mathrm{d}}$ & 1992 & Heterosexual & $\mathrm{F}$ & II & 494 \\
\hline RJ $491^{d}$ & 1992 & Bisexual & $\mathbf{M}$ & III & 965 \\
\hline RJ 623 & 1992 & Heterosexual & $\mathrm{F}$ & II & 799 \\
\hline RJ 625 & 1992 & Heterosexual & $\mathrm{F}$ & NA & 311 \\
\hline RJ 626 & 1992 & NA & $\mathbf{M}$ & II & 590 \\
\hline RJ 636 & 1992 & Heterosexual & $\mathbf{F}$ & IV & 015 \\
\hline RJ I01 & 1992 & Heterosexual & $\mathrm{F}$ & II & 1031 \\
\hline RJ I02 & 1992 & Heterosexual & $\mathbf{F}$ & II & NA \\
\hline RJ 103 & 1992 & Heterosexual & $\mathbf{F}$ & II & NA \\
\hline RJ I04 & 1992 & Heterosexual & $\mathbf{F}$ & II & 550 \\
\hline SP 1 & 1992 & Homosexual & $\mathbf{M}$ & II & $>500$ \\
\hline SP 2 & 1992 & Homosexual & $\mathbf{M}$ & II & $>500$ \\
\hline SP 3 & 1992 & Homosexual & $\mathbf{M}$ & II & $>500$ \\
\hline SP 4 & 1992 & $\begin{array}{r}\text { Homosexual and } \\
\text { blood product }\end{array}$ & $\mathbf{M}$ & IV & 200 \\
\hline
\end{tabular}

${ }^{a}$ RJ, Rio de Janeiro; SP, Sãn Paulo.

${ }^{b}$ Heterosexual females, sexual partners of HIV-seropositive individuals; heterosexual males, sexual intercourse with prostitutes. IVDU, Intravenous drug user.

${ }^{c}$ NA, Not available.

Samples not amplified with env primer sets. 
immunofluorescence assay (IFA), and Western blot tests, and were scored according to Centers for Disease Control (CDC) clinical classification. $\mathrm{CD}^{+}$cell evaluations were done by flow cytometry.

\section{DNA preparation from peripheral blood mono nuclear cells}

Genomic DNA was extracted by the proteinase $\mathrm{K}$-sodium dodecyl sulfate (SDS), organic extraction method from $10^{6}$ PBMCs purified by Ficoll-Hypaque density centrifugation. Briefly, pelleted cells were resuspended in $200 \mathrm{ml}$ of $50 \mathrm{mM}$ Tris- $\mathrm{HCl}$ ( $\mathrm{pH} \mathrm{7.8),} 10 \mathrm{mM}$ ethylenediaminetetraacetic acid (EDTA), containing $1 \% \mathrm{SDS}$ and proteinase $\mathrm{K}(100 \mathrm{mg} / \mathrm{ml})$, incubated at $37^{\circ} \mathrm{C}$ overnight, extracted with phenol (v:v), phenol-chloroform, and chloroform, and then ethanol precipitated. The samples were resuspended in $20 \mathrm{ml}$ of water and the concentration of DNA evaluated by agarose gel electrophoresis in comparison to a known concentration of DNA.

\section{Polymerase chain reaction amplification of $H I V-1$ env sequences}

DNA (200 to $500 \mathrm{ng}$ ) from each sample was used as template for the amplification of a region of the env gene including a portion of $\mathrm{C} 2$ through $\mathrm{V} 3, \mathrm{~V} 4$, and V5, using a nested protocol. ${ }^{24}$ In the first round, primers ED3 (5'. TTAGGCATCTCCTATGGCAGGAAGAAGCGG) (positions 5956-5986 of the HXB2 genome) and ED12 (5! AGTGCTTCCTGCTGCTCCCAAGAACCCAAG) (positions 7792-7822) were used. Aliquots $(5 \mathrm{ml})$ of the first PCR round were reamplified using ES7 (5' TGTAAAACGACGGCCAGTCTGTTAAATGGCAGTCT AGC) (positions 7001-7021) and ES8 (5' CAGGAAACAGCTATGACCCACTTCTCCAATTGTCCCCACA) (positions 7646-7667) primers. The PCR conditions consisted of 3 cycles at $97^{\circ} \mathrm{C}(1 \mathrm{~min}), 55^{\circ} \mathrm{C}(1 \mathrm{~min})$, and $72^{\circ} \mathrm{C}(2 \mathrm{~min})$, followed by 32
Amplification and cloning of HIV-I DNA from peripheral blood mononuclear cell DNA

DNA of sample RJ IO3, which could not be amplified with the above set of env primers, was successfully amplified using ED3 (5' TTAGGCATCTCCTATGGCAGGAAGAAGCGG, positions 5956-5985 of the HXB2 genome) and ED14 env primers (5' TCTTGCCTGGAGCTGCTTGATGCCCCAGAC, positions 7931-7960 of the HXB2 genome) in the first round (using the same buffer as in the first round described above). For the second round, the J-5'-2KSI and J-3'-2-KSI-2 primers of Wolfs et al..$^{26}$ (5' caucaucaucauGCAGUCUAGCAGAAGAAGA and $5^{\prime}$ cuacuacuacuaUUCUGGGUCCCCUCCUGAGGA [positions 7011-7029 and 7333-7313 on HXB2, respectively]) were modified for use with the Clone-Amp kit (GIBCO-Bethesda Research Laboratories [BRL], Gaithersburg, MD). The amplification buffer contained $3 \mathrm{mM} \mathrm{MgCl}_{2}$. The resulting PCR fragment contained the V3 loop and flanking regions, and was digested with uracil DNA glycosylase to cleave uracil-containing primers, annealed with pAMP1 vector DNA (GIBCO$\mathrm{BRL}$ ), and transformed into Escherichia coli DH5 $\alpha$ cells (GIBCO-BRL). Plasmid DNA from a miniprep derived from an individual colony was prepared using a Qiagen-tip 20 column (Qiagen, Chatsworth, CA), and sequenced with Sequenase version 2.0 (United States Biochemical).

\section{Nucleotide sequence analysis}

Direct sequencing of HIV-1 PCR product without cloning yielded a consensus nucleotide sequence of the predominant V3 loop and flanking regions for all samples except RJ IO3. The RJ IO3 sequence was derived from a single provirus. Nucleotide and predicted amino acid sequences were aligned with each other and with a set of available envelope subtype B HIV-1 isolates, ${ }^{5}$ using the program MASE. ${ }^{27}$ A phylogenetic tree was constructed using the PHYLIP 3.5c package of computer programs. ${ }^{28}$ The branching order was determined using DNADIST 


\section{Polymerase chain reaction of env DNA from Brazilian patients}

A region of the viral envelope gene (env) consisting of the $\mathrm{V} 3$ loop with flanking regions was PCR amplified directly from PBMC DNA and the product sequenced without subsequent cloning. This yielded the majority sequence present within the PBMCs of 27 of 32 individuals. The remaining 5 DNA samples could not be PCR amplified using the first set of nested primers specified in Materials and Methods. Proviral DNA from the five remaining negative samples, were, however, successfully amplified (data not shown) using a nested set of primers specific for the first exon of the tat gene, ${ }^{29}$ suggesting that viruses within these individuals might be divergent at primer annealing sites within $e n v$. Indeed, the $e n v$ gene of one of these remaining sequences, sample RJ IO3, could be PCR amplified using a different nested set of $e n \nu$-specific primers (see Materials and Methods). Insufficient DNA was available from the other four samples (RJ 33, RJ 370, RJ 485, RJ 491) to allow amplification with the second set of $e n v$ specific primers.

\section{Definition of subgroup $B$ and $F$ sequences in Brazilian samples}

The alignment of the deduced amino acid sequences from the 28 Brazilian samples evaluated in this study is presented in Fig.
1. Twenty-two of the 28 samples were sequenced over the entire V3 region shown, whereas partial sequences from the remaining 6 samples were obtained. The average nucleotide diversity among a subset of these sequences (excluding RJ IOI and RJ IO3) in the region shown in Fig. 1 is $13.5 \%$, and ranged between 7.3 and $21.4 \%$ for all pairwise comparisons. Some positions at the tip of the V3 loop and the flanking region downstream from the V3 loop were highly divergent, with three or more different amino acids in those positions.

Although six of the Brazilian samples analyzed were not sequenced for the entire region shown in Fig. 1, enough sequence was obtained to determine that, with the exceptions of RJ IOI and RJ IO3, all samples belong to subtype B. Divergence from the published subtype $B$ sequences included in Fig. 2 ranged from $6.3 \%$ (RJ 54 vs. JRCSF) to $20.7 \%$ (SP 3 vs. CDC42). The RJ IO3 sequence was distinct in that it showed a 22.5 to $28.4 \%$ divergence from the subtype B Brazilian sequences, and a 23.6 to $31.7 \%$ difference from representative sequences of the A-E subtypes included in Fig. 2. However, RJ IO3 was only $8.3 \%$ divergent from HIV sequence 7944 described in $\mathrm{Brazil}^{21}$ and 11.8 to $14.9 \%$ divergent from several characterized sequences from Romanian children ${ }^{30}$ (Figs. 1 and 2). Therefore, RJ IO3 and the unique 7944 sequence from Brazil described by Potts et al. ${ }^{21}$ can be classified as members of the newly identified HIV-1 envelope sequence subtype F.,24.30-32 Interestingly, the differences between RJ IO3 and other Brazil-

\begin{tabular}{|c|c|}
\hline & $1<--$ \\
\hline SONS & 1IVQLNES VEINCTRPNNNTRKS I I IGWG-RAFYATGEI IGD IRQAHCN \\
\hline & .K.Е..Е...К....-- \\
\hline ل & 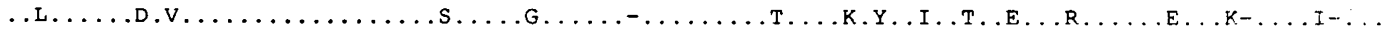 \\
\hline RJ14 & І $\ldots$ н. . \\
\hline RJ5 & I $\ldots-\ldots \ldots$ А. . . \\
\hline RJ64 4 & 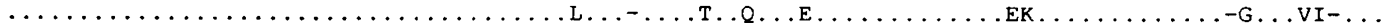 \\
\hline RJ62 & 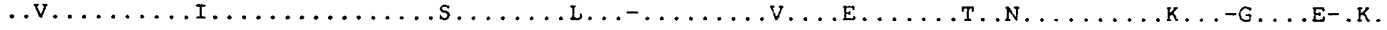 \\
\hline J7 & ..s. \\
\hline RJ 4 & 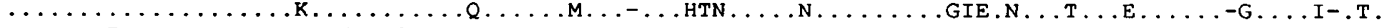 \\
\hline $\mathrm{J} 49$ & 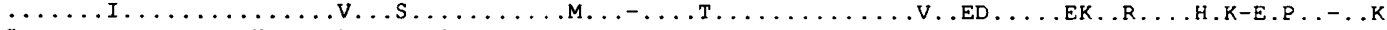 \\
\hline 21 & $1 \ldots \ldots \ldots \ldots$. $\ldots \ldots$. . . . . . . . \\
\hline 22 & 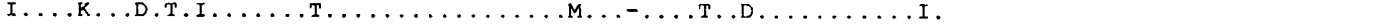 \\
\hline J4 3 & 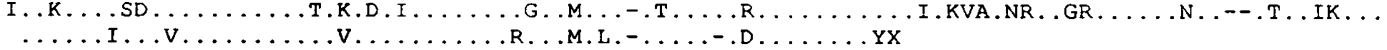 \\
\hline RJ 483 & 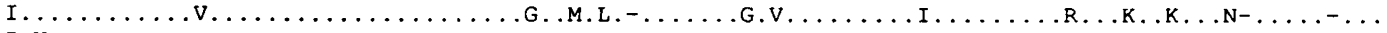 \\
\hline RJIC & 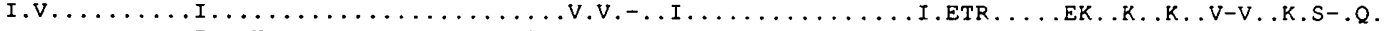 \\
\hline RJIO4 & 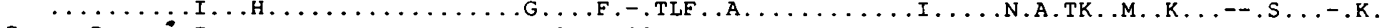 \\
\hline RJ1 & G....D............. \\
\hline RJ17 & $\cdots \cdots \cdots$ \\
\hline RJ27 & . GG. INKEN. \\
\hline J3 3 & 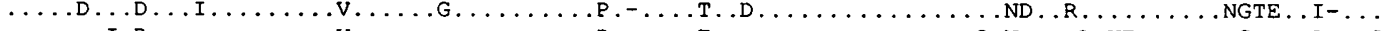 \\
\hline RJ5 4 & $\ldots \ldots$ I.D. $\ldots \ldots \ldots$ V. $\ldots \ldots \ldots \ldots$. \\
\hline RJ623 & .S. . .R. .L.P. -G...T. . . .N. .K.F.T.NGT..E. \\
\hline RJ 625 & 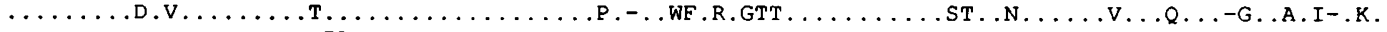 \\
\hline J6 & 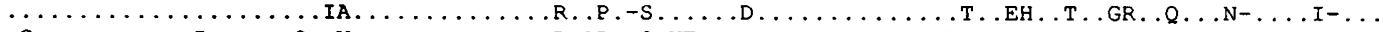 \\
\hline RJ636 & K.....-E....Q- \\
\hline SP4 4 & .KR.ND...I. \\
\hline $\mathrm{NA}-$ & 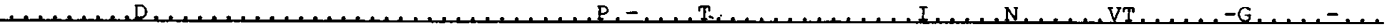 \\
\hline JIOL1 & 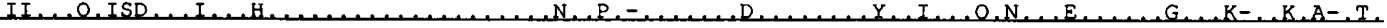 \\
\hline 3 & ............. KVHGTQ \\
\hline 794 & SH.P-.A. .K-..S \\
\hline RMA & 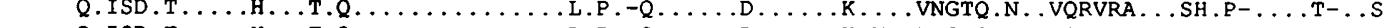 \\
\hline RME & ..K.Y..V.GTQ.N. .VQRVRA. .KSH.P- . .T- . T \\
\hline MF & 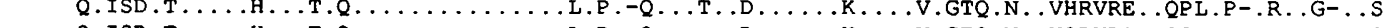 \\
\hline 2MJ & ...K...V.V.GTQ.N. .VQRVRA. .QSH.P-...T-..S \\
\hline
\end{tabular}

FIG. 1. The alignment of Brazilian, B subgroup consensus HIV-1 and F subgroup sequences in the V3 region. The putative recombinant sequence $\mathrm{RJ} I O 1$ is shown between $B$ subgroup sequences above it and F subgroup below. Consensus sequences were generated separately for all Brazilian and North American/European B subtype sequences shown in Fig. 2. Amino acids identical to the Brazilian subtype B consensus sequences are shown as dots. Four most divergent sequences from Romanian children ${ }^{30}$ and $F$ subtype sequence 7944 from Brazil ${ }^{21}$ (GenBank accession numbers L19571, L19575, L19576, L19579, and L19237, respectively) are also shown. 


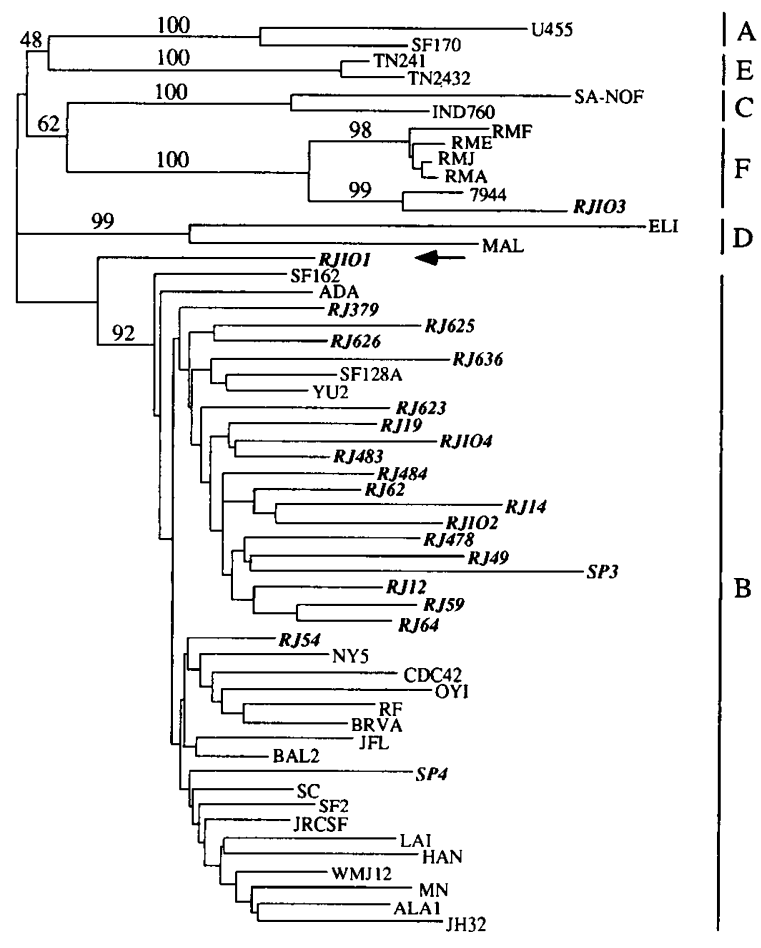

FIG. 2. Phylogenetic tree for 22 Brazilian HIV-I sequences deseribed in this article (shown in bold italics), 20 subtype B sequences, 5 subtype $F$ sequences, and representative sequences from other HIV-1 subtypes. The tree was generated for the fragment of the envelope gene shown in Fig. 1, excluding the first 15 nucleotides not sequenced in the Romanian samples. ${ }^{30}$ Only completely sequenced Brazilian C2V3 sequences were included. Phylogenetic analysis was done using the PHYLIP programs $^{28}$ (see Materials and Methods). The numbers near the major branches show how many times out of 100 bootstrap repetitions the sequenes to the right clustered together (putative recombinant virus RJ IOI was excluded from bootstrap analysis). HIV-1 isolates are from the following countries: all B subtype from the United States, except OYI (accession number M26727) from Gabon and HAN ${ }^{5}$ from Germany; 7944 from Brazil; ELI (K03454) and MAL (K03456) from Zaire; RM from Romania; SA-NOF (L07426) from South Africa; IND from India (5); TN from Thailand (L03700 and L03703); U455 (M62320) from Uganda; and SF170 (M66535) from Rwanda.

ian sequences were mainly localized in the regions flanking the V3 loop rather than within the loop itself (Fig. 1).

In the phylogenetic analysis shown in Fig. 2, the 22 longest Brazilian sequences were analyzed together with HIV-1 env sequences representing subtypes $A-E^{5}$ and subtype $F$. This analysis confirms that the Brazilian sequences (shown in bold italics) belong to the $B$ and $F$ subtypes with $B$ predominating.

The N-terminal region of the RJ IOl sequence shown in Fig. 1 seems to match the subtype $F$ sequences better than the subtype $B$ sequences. However, the remaining part of the sequence is more similar to subtype B sequences. There are four amino acid changes (Q.IS.H in Fig. 1) and two silent mutations (not shown) present in the $\mathrm{N}$-terminal region of $\mathrm{RJ} \mathrm{IO} 1$ and all of the subtype F sequences in Fig. 1, which are either not present, or are rare, in the corresponding region of subtype B sequences. The potentially recombinational origin of RJ IO1 is also evident in Fig. 2, where it is positioned as an intermediate between $B$ and other subtypes. Additional sequencing of RJ $\mathrm{IO1}$ and RJ IO3 is in progress to address the hypothesis that $\mathrm{RJ} I O 1$ is a recombinant between $B$ and F HIV-1 subtypes. It is noteworthy that the one subtype $F$ sequence and the putative $B / F$ recombinant sequence (RJ IO3 and RJ IO1, respectively) were obtained from recent seroconverters.

\section{Differences between Brazilian and North American/ European subtype B V3 loop sequences}

Only $23 \%$ of the 26 subtype B Brazilian sequences analyzed had the GPGR motif in the tip of the V3 loop that, in contrast, is conserved within $65 \%$ of the North American/European viruses. ${ }^{5}$ The Brazilian subtype F sequences RJ IO3 and $7944^{21}$ and the putative recombinant sequence RJ IO1 all had the GPGR motif, whereas the Romanian subtype F sequences had GPGQ. The Romanian sequences also had other characteristic amino acids outside of this motif (Fig. 1). The GWGR tetrapeptide was present in $43 \%$ of the Brazilian samples analyzed, whereas $29 \%$ had different motifs, such as GLGR, GPGG, and GGGR, among others. The frequency of variants in the octameric scyuunce at the tip of the V3 loop from Brazilian HIV-1 samples was compared to 159 North American/European subtype B samples $^{5}$ in Table 2. Eighteen of 28 Brazilian samples analyzed (64\%) were unique to Brazil, including the ostamer HLGWGRAF, which was present in 4 of 28 samples analyzed (14\%). This demonstrates significant amino acid differences between Brazilian and North American HIV-1 envelopes in this immunologically important epitope.

A comparison of the $\mathbf{3 5}$ amino acids corresponding to the V3 loop between Brazilian subtype B HIV-1 samples and some prevalent North American/European HIV-1 strains under evaluation for use in vaccine development showed that the level of conservation with the LAI (former BRU) strain was low, ranging from 56 to $75 \%$ (mean, $66 \%$ ). For the prevalent $\mathrm{MN}$ strain V3 loop, the conservation with Brazilian samples ranged from 64 to $83 \%$ (mean, $71 \%$ ) whereas higher levels were obtained when compared to the SF2 or SC strains (71 to 91\%; mean, $79.5 \%$ ). The similarity values between the North America/European consensus sequence and these various strains are on average higher $(75,83,89$, and $89 \%$, respectively).

\section{Sequencing of tissue culture isolates}

Comparison of the amino acid sequences obtained by direct sequencing of PCR product from PBMCs with those obtained after a single PBMC cocultivation passage ${ }^{32}$ yielded similarities of 96 and $93 \%$ for sample pairs from subjects RJ 623 and RJ 625 , respectively (data not shown). This suggests that the sequences obtained directly from PCR products of PBMC proviruses are highly related to the sequences of replication-competent viruses obtained after a single passage in PBMCs. Primary isolates recovered after cocultivation from nine Brazilian PBMC samples $^{33}$ will be useful for the evaluation of antigenic variability of Brazilian HIV-1 strains in functional assays such as viral neutralization. 
TABle 2. Frequency of V3 LoOP OCTAMERIC TiP SEQUENCES IN BRAZILIAN HIV-1 AND NORTH AMERICAN/ EUROPEAN SUBTYPE B VIRUSES

\begin{tabular}{|c|c|c|}
\hline \multirow[b]{2}{*}{ Sequence } & \multicolumn{2}{|c|}{ Number (\%) with the sequence } \\
\hline & $\begin{array}{c}\text { Brazil } \\
(n=28)\end{array}$ & $\begin{array}{c}\text { Non-Brazilian, } \\
\text { subtype } B \\
(n=159)^{a}\end{array}$ \\
\hline \multicolumn{3}{|l|}{ Subtype B } \\
\hline H L G W G R A F & $4(14.0)$ & $\mathbf{0}$ \\
\hline H M G W G R A F & $4(14.0)$ & $3(1.9)$ \\
\hline H I G P G R A F & $3(11.0)$ & $33(21.0)$ \\
\hline H M G L G R A F & $2(7.0)$ & $\mathbf{0}$ \\
\hline H I G W G A F & $1(3.6)$ & $\mathbf{0}$ \\
\hline H M G W G R T F & $1(3.6)$ & $2(1.3)$ \\
\hline H V G W G R A L & $1(3.6)$ & 0 \\
\hline H I G P G R A W & $1(3.6)$ & $\mathbf{0}$ \\
\hline$S$ I G P G R A F & $1(3.6)$ & $9(5.7)$ \\
\hline H M G P G R A Y & $1(3.6)$ & $\mathbf{0}$ \\
\hline$N$ I $\quad$ P G R A F & $1(3.6)$ & $6(3.8)$ \\
\hline Q Y G T G G G A & $1(3.6)$ & 0 \\
\hline H I G W G R A I & $1(3.6)$ & 0 \\
\hline R I G P G S A F & $1(3.6)$ & 0 \\
\hline$P$ I A P G S A W & $1(3.6)$ & 0 \\
\hline H I G F G R T L & $1(3.6)$ & 0 \\
\hline$H V G V G R A F$ & $1(3.6)$ & 0 \\
\hline$P L G P G R A F^{c}$ & $1(3.6)$ & 0 \\
\hline$H \cdot L \quad G P G G A F$ & $1(3.6)$ & $\mathbf{0}$ \\
\hline$P$ I $G$ P $\mathrm{G} A \mathrm{~F}$ & $\mathbf{0}$ & $11(7.0)$ \\
\hline H I A P G A F & 0 & $6(3.8)$ \\
\hline T I G P G R A F & 0 & $6(3.8)$ \\
\hline Other & 0 & $83(52.2)$ \\
\hline
\end{tabular}

${ }^{a}$ From Ref. 5.

${ }^{b}$ RJ I01, Putative subtype B/F recombinant.

${ }^{c}$ RJ I02, Subtype F. studies will be necessary to evaluate the frequency of subtype $F$ in Brazil, and the variation seen in the $\mathrm{V} 3$ region of this subtype. It should be noted that 5 of the 32 Brazilian samples analyzed here $(15 \%)$ were not successfully amplified with 1 set of nested $e n v$-specific primers. The RJ IO3 subtype F sample was one of these five samples, and yielded amplified DNA only with another set of $e n v$-specific primers. Although insufficient DNA from the other four samples precluded further analysis, it is possible that they too contained $\mathrm{F}$ (or other divergent) subtype genomes.

The average nucleotide diversity in the V3 region within the Brazilian subtype B samples was $13.5 \%$, which is similar to the $11.2 \%$ average observed among the non-Brazilian subtype B sequences shown in Fig. 2. This suggests that HIV-1 has been circulating in the Brazilian population for approximately the same period as in the United States. ${ }^{24}$ This contrasts with the relatively recent spread of HIV- $\mathrm{r}$ infection in Thailand ${ }^{35}$ and India ${ }^{36}$ which has been characterized by a high degree of sequence conservation among the HIV-1 isolates from epidemiologically unrelated individuals.

Differences in the critical tetrapeptide "crown" of the V3 loop ${ }^{5,13-16}$ are seen when the Brazilian subtype $B$ sequences are compared to North American/European type B sequences. Whereas the GPGR tetrapeptide is present in $65 \%$ of North American/European samples so far analyzed, ${ }^{5}$ it is present in only $28.5 \%$ of Brazilian sequences presented here. Eighty-seven percent of North American/European sequences contain proline (P) in the second position, ${ }^{5}$ compared to $39 \%$ of the Brazilian sequences, whereas $43 \%$ have tryptophan $(\mathrm{W})$ and $18 \%$ have other amino acids. High variability in the V 3 crown tetrapeptide has also been found in non-B subtypes, where only $39 \%$ of isolates have proline at the second position. ${ }^{37}$ However, a majority of non-B HIV-1 sequences ( 16 of 18 subtype A, C, D, and $E$ sequences, compiled in Ref. 5) contain glutamine $(Q)$ at the fourth position, whereas Brazilian ( $86 \%$ of sequences ana-

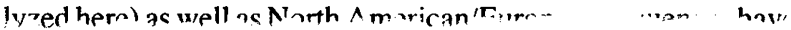


Also relevant is the previous study by Bongertz et al. ${ }^{23}$ which showed low reactivity of sera from HIV-1-infected Brazilians when tested against peptides corresponding to the region just downstream from GPGR in the V3 loop of the HIV-1 MN and $\mathrm{SC}$ isolates, described as predominant serotypes in North America and Europe.

In addition to showing important differences when compared to North American/European HIV-1 isolates, Brazilian sequences also show a high degree of variation in the V3 region. A frequent change of the IHI motif in the V3 loop to IHM or IHL was detected in the samples analyzed here, in addition to variability in regions flanking the V3 loop. These amino acid changes predict variation in glycosylation and net charge in this region.

Findings similar to those presented here have been published by Potts et al. ${ }^{21}$ including detection of one example of what is now referred to as subtype $F,{ }^{5,24,30}$ with the interesting difference that most of their samples were obtained from the Bahia region of Brazil to the north of Rio de Janeiro and São Paulo.

The immunological impact of the significant differences observed here between Brazilian and North American/European isolates, and the variability seen among the Brazilian isolates in sequences important for neutralizing antibodies and cytotoxic $\mathbf{T}$ cells, should be taken into account for future immunoprophylactic programs to be established in Brazil.

\section{ACKNOWLEDGMENTS}

This work was partially supported by Grants RO:1-HL -48367 and RO1-AI-32885 (NIH), by the NAID/PAHO/Brazilian Ministry of Health; and by the AIDS Program/FIOCRUZ/Brazilian Ministry of Health.

\section{REFERENCES}

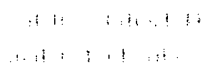

1. Asjö B, Albert J, Karlsson A; Morfelt-Månson, Biberfeld G, Lidman K, and Fenyö EM: Replicative properties of human immunodeficiency, virus from patients with varying severity of HIV infection. Lancet 1986;ii:660-662.

2: Cheng Mayer $C_{1}$, Homsy J; Evans LA, and Levy JA: Identification

: of human immunqdeficiency virus;subtypes with distinct patterns of sensitivity to serum neutralization :Proc Natl Acad Sci USA 1988;85:2815-2819.

3. Tersmette $M_{4}$ Gruters RA, de Wolf F, de Goede REY, Lange JMA, Sohellekens PTA! Goudsmit J, Huisman HG, and Miedema F:

i) Evidence for a role of virulent human immunodeficiency virus (HIV) variants in the pathogenesis of acquired immunødeficiency syndrome: Studies on sequential HIV isolates. J Virol 1989;63:2118-2125.

4. Simmonds PP, Zhang LQ, McOmish F, Balfe P, Ludlam CA, and Brown AJL: Discontinuous sequence change of human immunodeficiency virus (HIV) type 1 env sequences in plasma viral and lymphocyte-associated proviral populations in vivo: Implications for models of HIV pathogenesis. J Virol 1991;65:6266-6276:

5. Myers G, Korber B, Wain-Hobson S, Smith RF, and Pavlakis GN (Eds.). Human Retroviruses and AIDS 1993: A Compilation and Analysis of.Nucleic. Agid and Amino Acid Sequences! Los Alamos National Laboratory, Los Alamos, New Mexico, 1993.!

6.. Kusumi K, Conway B, Cunningham S, Berson A, Evans C, Iversen AKN, Colvin D, Gallo MV, Coutre S, Shpaer EG; Faulkner DV,
deRonde A, Volkman S, Williams C, Hirsch MS, and Mullins JI: Human immunodeficiency virus type 1 envelope gene structure and diversity in vivo and after co-cultivation in vitro. J Virol 1992;66:875-885.

7. Wolfs TF, Nara PL, and Goudsmit J: Genotyping and phenotypic variation of HIV-1: Impact on AIDS pathogenesis and vaccination. Chem Immunol 1993;56:1-33.

8. Shioda T, Levy JA, and Cheng-Mayer C: Macrophage and T-cell line tropisms of HIV-1 are determined by specific regions of the envelope gp120. Nature (London) 1991;349:167-169.

9. Takeuchi Y, Akutsu M, Murayama K, Shimizu N, and Hoshino H: Host range mutant of human immunodeficiency virus type 1 ; modification of cell tropism by a single point mutation at the neutralization epitope in the env gene. J Virol 1991;65:1710-1718.

10. Hwang SS, Boyle TJ, Kim-Lyerly H, and Cullen BR: Identification of the envelope V3 loop as the primary determinant of cell tropism in HIV-1. Science 1991;253:71-74.

11. Fouchier RAM, Groenink M, Kootstra NA, Tersmette M, Huisman HG, Miedema F, and Schuitemaker H: Phenotype-associated sequence variation in the third variable domain of the human immunodeficiency virus type 1 gp120 molecule. J Virol 1992;66:31833187.

12. Kuiken CL, de Jong J-J, Keulen W, Tersmette M, and Goudsmit J: Evolution of the $\mathrm{V} 3$ envelope domain in proviral sequences and isolates of human immunodeficiency virus type 1 during the transition of the viral biological phenotype. J Virol 1992;66:46224627.

13. Palker TJ, Clark ME, Langlois AJ, Matthews TJ, Weinhold KJ, Randall RR, Bolognesi DP, and Haynes BF: Type-specific neutralization of the human immunodeficiency virus with antibodies to env-encoded synthetic peptides. Proc Natl Acad Sci USA 1988;85:1932-1936

14. Javaherian K, Langlois AJ, McDanal C, Ross KL, Eckler LI, Jellis CL, Profy AT, Rusche JR, Bolognesi DP, Putney SD, and Matthews TJ: Principal neutralizing domain of the human iminunodeficiency virus type envelope protein: Proc Natl Acad Sci USA 1989;86:6768-6772.

15. Goudsmit J; Debouck C, Meloen RH, Smit L, Bakker M, Asher DM; Wolff AV, Gibbs CJJ, and Gajdusek C: Human immunodeficiency virus type 1 neutralization epitope with conserved architecture elicits early type-specific antibodies in experimentally infected chimpanzees. Proc Natl Acad SciUSA 1988;85:4478 14482 .'

16. LaRosa GJ, Davide 'JP, Weinhold K,' Waterbury' 'K!'Profy: AT,

1. Lewis JA; Langlois AJ; Dreesman GR, Boswell RN, Shadduck P,

1... Holley LH, Karplus M,'Bolognesi DP, Mathe'w's TJ; :Emini EA, 1: and Putney! SD! Conserved sequence and strictural eletrents in the . HIV 1 principal neutralizing determinant: Science 1990;249:932935:

17. Takahashi H, Cohen J, Hosmalin A, Cease KB, Houghton R, 'Cornette JL; Delisi C, Moss B', Germain RN, and Berzofsky JA: An immunodominant epitope of the human immunodeficiency virus envelope glycoptotein gp160' recognized by' class! I' inajor histocompatibility complex molecule-restricted muriné cytotoxic $\mathbf{T}$ lymphocytes. Proc Natl Acad Sci USA 1988;85:3105:3109.

18. Takahashi H, Nakagawa Y; Pendleton CD, Houghton RA; Yokomuro $\mathrm{K}$, Germain RN; and Berzofsky JA: Indudetion of broadly cross-reactive cytotdxic $\mathrm{T}$ cells recognizing an HIV -1 envelope

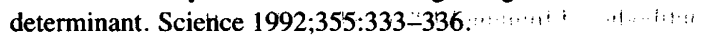

19. Palker 'TJ, Matthew's' TJ, Langlois A,' Tảnner ME, Martin' ME, Scearce RM; Kim JE; Berzofsky 'JA, Bolognesi' DP; and Haynes BF: Polyvalent human imimunodeficiency virus synthetic itmmunogen comprised of envelope gp120 T helper cell sites and B cell neutralization epitopes. J Immunol 1989;142:3612-3619!! :

20. Couto-Fernandez J-C, Morgado MG, Ivo-dos-Santós J; and Galvao-Castro B: Molecular 'and biological divetsity' of HIV:1 in Brazil: Mem Inst Oswaldo Cruz 1992;87:249-255. 
21. Potts K, Kalish M, Lott T, Orloff G, Luo C-C, Bernard M-A, Alves C, Badaro R, Suleiman J, Ferreira O, Schochetman G, Johnson W $\mathrm{Jr}, \mathrm{Ou} \mathrm{C}-\mathrm{Y}$, and Ho J: Genetic heterogeneity of the V3 region of the HIV-1 envelope glycoprotein in Brazil. AIDS 1993;7:1191-1197.

22. Carrow EW, Vujcic LK, Glass WL, Seamon KB, Rastogi SC, Hendry RM, Boulos R, Nzila N, and Quinnan GV Jr: High prevalence of antibodies to the gp120 V3 region principal neutralizing determinant of HIV-1MN in sera from Africa and the Americas. AIDS Res Hum Retroviruses 1991;7:831-838.

23. Bongertz V, Jonsson M, Flodby $P$, Morgado MG, Galvão-Castro $B$, and Wigzell $H$ : Reactivity of Brazilian sera with gp120 V3 peptides. Brazilian J Med Biol Res 1994:27.

24. Delwart EL, Shpaer EG, Louwagie J, McCutchan FE, Grez M, Rübsamen-Waigmann $\mathrm{H}$, and Mullins JI: Genetic relationships determined by a DNA heteroduplex mobility assay: Analysis of HIV-1 env genes. Science 1993;262:1257-1261.

25. Burger H, Weiser B, Flaherty K, Gulla J, Nguyen P-N, and Gibbs RA: Evolution of human immunodeficiency virus type 1 nucleotide sequence diversity among close contacts. Proc Natl Acad Sci USA 1991;88:11236-11240.

26. Wolfs TFW, Zwart G, Bakker M, and Goudsmit J: HIV-I genomic RNA diversification following sexual and parenteral virus transmission. Virology 1992;189:103-110.

27. Faulkner DV and Jurka J: Multiple aligned sequence editor (MASE). Trends Biochem Sci 1988;13:321-322.

28. Felsenstein J: PHYLIP-Phylogeny Inference Package. Cladistics 1989;5:164-166.

29. Sabino E, Cheng-Mayer C, and Mayer A: An individual with a high prevalence of a tat-defective provirus in peripheral blood. AIDS

- Res Hum Retroviruses 1993;9:1265-1268.

30. Dumitrescu O, Kalish ML, Kliks SC, Bandea CI, and Levy JA: Characterization of HIV-1 strains isolated from children in Romania: Identification of a new envelope subtype. J Infect Dis 1994 369:283-288

31. Louwagie J, Delwart EL, Mullins JI, McCutchan FE, Eddy G, and Burke DS: Genetic analysis of HIV-1 isolates from Brazil reveals presence of two distinct genotypes. AIDS Res Human Retroviruses $\rightarrow$ er. tion of human immunodeficiency virus and effects of cell lysis on isolation efficiency. J Clin Microbiol 1987;25:1291-1294.

33. Hendry RM, Viral and Rickettsial Diseases Laboratory, California Public Health Foundation (Berkeley, CA): Unpublished results, 1993.

34. Sabino EC, Shpaer EG, Morgado MG, Korber BTM, Diaz R, Bongertz V, Cavalcante S, Galvão-Castro B, Mullins JI, and Mayer A: Identification of HIV-1 proviral genomes recombinant between subtypes B and F in PBMC obtained from two individuals in Brazil. Manuscript in preparation, 1993.

35. McCutchan FE, Hegerich PA, Brennan TP, Phanuphak P, Singharaj P, Jugsudee A, Berman PW, Gray AM, Fowler AK, and Burke DS: Genetic variants of HIV-1 in Thailand. AIDS Res Hum Retroviruses 1992;8:1887-1895.

36. Dietrich U, Grez M, von Briesen H, Panhans B, Geißendörfer M, Kühnel H, Maniar J, Mahambre G, Becker WB, Becker MLB, and Rübsamen-Waigmann H: HIV-1 strains from India are highly divergent from prototypic African and US/European strains, but are linked to a South African isolate. AIDS 1993;7:23-27.

37. Korber B, Wolinsky S, Haynes B, Kunstman K, Levy R, Furtado $M$, Otto $P$, and Myers G: HIV-1 intrapatient sequence diversity in the immunogenic V3 region. AIDS Res Hum Retroviruses 1992;8:1461-1465.

38. Hattori T, Shiozaki K, Eda Y, Tokiyoshi S, Matsushita S, Inaba H, Fujimaki M, Meguro T, Yamada K, Honda M, Nishikawa K, and Takatsuki K: Characteristics of the principal neutralizing determinant of HIV-1 prevalent in Japan. AIDS Res Hum Retroviruses 1991;7:825-830.

39. Gorny MK, Conley AJ, Karwoska S, Buschbinder A, Xu J-Y, Emini EA, Koenig S, and Zolla-Pazner S: Neutralization of diverse human immunodeficiency virus type 1 variants by an anti-V3 human monoclonal antibody. J Virol 1982;66:7538-7542.

Address reprint requests to: Mariza G. Morgado Department of Immunology Oswreldn rur Insti... 